\title{
A Successful Language Teaching Model: Switzerland Case
}

\section{Gökhan Kayır}

Dr., Turkish Embassy Department of Education, Berne/Switzerland, gokhankayir@gmail.com

Switzerland is like a language and culture pot with its four official languages and habitants from all over the world. The purpose of this study was to inspect this country's special language education model. The study was designed as a case study and data were gathered with document analysis. Curriculums and other publications were analyzed with context analysis technique. The findings showed that the Swiss language teaching model aims to raise plurilingual children who are open to other cultures. Also, common points of languages and cultures are always stressed. Not having a single official language, Switzerland has citizens who can speak more than one language with each other. New methods like Communicative, content and task-based techniques are used in language teaching.

Keywords: language education teaching, language, teaching model, Switzerland, teaching

\section{INTRODUCTION}

When you sit in your seat at a train in Switzerland and listen to the people, you can hear a lot of languages and dialects. Then a train conductor comes and speaks with you not only in German or English but also Italian and French. The case is the same as a waiter or a salesman. After finishing compulsory education, a Swiss student can speak at least his/her native language, another country's official language and English.

Switzerland and the Swiss educational system are doing very well. Although the country has very few natural resources, the economy is fairly stable and hardly affected by economic crises. The unemployment rate has for many years remained around $3.5-4 \%$, which is very low in comparison with other countries. Switzerland faces high amounts of immigration and its population currently consists of $22 \%$ of foreigners, speaking many different languages in addition to the 4 official languages. Nevertheless, the difficulties surging in the educational system are well coped with (Frei, 2011).

The most important problem for Switzerland seems the immigrants and integration. The policymakers are aware of these problems and trying to provide an education with equal rights. PISA showed Switzerland as being among the $10 \%$ of countries showing the least equity in terms not only of the reading disadvantage of non-native students, but also concerning differences between the top and bottom quarter of parents' occupational status and the distribution of teacher qualifications. The very low equity on the first two dimensions is due to the widespread selectiveness of school systems that leads to a segregation of schools where low-status and/or foreign-born students are overrepresented in lower tracks and high-status and/or native students in higher tracks. PISA has shown, that native students have better test results than non-natives (Fredriksson, Holzer, McCluskey-Cavin \& Taube, 2009).

What makes Swiss Education System unique? That question has many answers but the first one of them is "There is no single education system in Switzerland. In fact, there are 26 of them." As the country run with the federal system. The decisions about education are taken by local authorities. 
There are 26 cantons and therefore 26 ministries of education which take into account the cultural differences between them.

The state can be divided into 4 different linguistic and cultural areas. These areas are byzantine in some districts but can be understood by language shift. \%63 of the Swiss people speaks Swiss German which is the largest language population in the country. The second language group is French speakers with the percentage of $\% 22,7$ and the third group speaks Italian (\% 8.4). The smallest group consists of Romansh speakers with the percentage of \% 0.6 (Wikipedia, 2018)

The cantons have their own official languages. Cantons, close to Germany and Austria gives education in German while Swiss-Romande part (close to France) accepts French as the official language. One canton speaks Italian and cantons Fribourg, Bern, Valais and Graubünden has more than one official language. There are schools in both official languages in these cantons (Ronan, 2016).

The language of school education changes according to the language zone of the schools. The education is given in the four official languages of Switzerland: German, French, Italian or Romansh. Especially for Romansh students, their school language is very important as this language has very few speakers. During their school time, students learn a second official language and English (EDK, 2017).

For a long time, a native language of Switzerland had given as first foreign language but this situation changed on the side of English. For Example, the canton of Zurich decided, in December 1997, to increase the proportion of English in the compulsory school syllabus, while reducing the proportion of French (Fulgenzi, 2007)

The English language plays an important role in many areas of public and private life in Switzerland. English words and expressions, such as "sorry, cool or oh my God", are used in all the national languages of Switzerland. As there are many international companies and workers from different nations, English is a communication language and large population groups are able to speak English and use it regularly in business, education or travel contexts. (Ronan, 2016). English was, until after the First World War, the second foreign language after German or French in the respective parts of the country; then, however, as elsewhere in Europe, English established itself as a core subject (Engler, 2008).

With its immigrants, almost all of the world languages can be heard in Switzerland. Even though Switzerland takes pride in this multilingualism, it does not necessarily mean that the Swiss are multilingual. Language contact can only be found in some border areas. A symbolic choice of languages can be seen in Switzerland's official name that is reflected in the Latin name Confoederatio Helvetica (Swiss Confederation). The state treats four languages equal and for this reason, they chose a neutral language "latin" for the countries official name (Kużelewska, 2016). In a multilingual, federal state such as Switzerland, language learning and, consequently, language teaching, gain much importance.

On the basis of the School Agreement of 29 October 1970, the EDK on 30 October 1975 adopted recommendations and decisions regarding the introduction, reform and coordination of the teaching of the second national language to all pupils during their compulsory schooling (Hutterli, 2012).

This paper was written to examine language policy and teaching frame of Switzerland. To succeed this end, a general frame of the language lessons was drawn at each school level and then teaching technics and focus were analyzed.

\section{METHOD}

This study designed as a case study. According to Flyvbjerg (2011) case study is a detailed examination of a single example, but a case study can also provide reliable information about the 
broader class. It is also correct that a case study can be used in the preliminary stages of an investigation to generate hypotheses. In case studies, researchers try to understand the particularity and complexity of a single case, coming to understand its activity within important circumstances (Stake, 1995).

The data were gathered with document analysis method. Organizational and institutional documents have been an important source in qualitative research for many years. In recent years, there has been an increase in the number of research reports and journal articles that mention document analysis as part of the methodology (Bowen, 2009). Documents serve as substitutes that researchers cannot observe directly (Stake, 1995).

Document analysis process consists of skimming, reading, and interpretation. This method combines elements of content analysis and thematic analysis. Content analysis is the process of organizing information into categories related to the main questions of the research (Bowen, 2009). Thus, to get the correct findings, content analysis method was used in this research.

\section{Procedure}

The research is made according to the content analysis procedure, which is defined by White and Marsh (2006);

1. Establish hypothesis or hypotheses

2. Identify appropriate data (text or other communicative material)

3. Determine the sampling method and sampling unit

4. Draw sample

5. Establish data collection unit and unit of analysis

6. Establish coding scheme that allows for testing hypothesis

7. Code data

8. Check for the reliability of coding and adjust the coding process if necessary

9. Analyze coded data, applying appropriate statistical test(s)

10. Write up results

According to this procedure, firstly, the scope of documents are determined which are the policy reports published by The Conference of Swiss Educational Directors, language lesson curriculums, the articles which have the keywords " Swiss language education", "language education in Switzerland" "language education, Switzerland". The languages of the documents are limited as English, German and French.

The coding schema is defined as the research questions of the study and the data were coded according to these questions. The coding procedure is discussed with two experts to check the validity of the study.

\section{FINDINGS}

\section{Language Teaching Policy of Switzerland}

Switzerland has a strong and traditional language policy. Even though it is not a member of the European Union, the country signed many treaties of the union. Language teaching and evaluation processes are the same as the ones in European countries. Following the CEFR (The Common 
European Framework of Reference for Languages), language teaching models and certificates become valid in European Countries. Also, Swiss schools are members of different student Exchange programmes that enable students to experience a student life abroad.

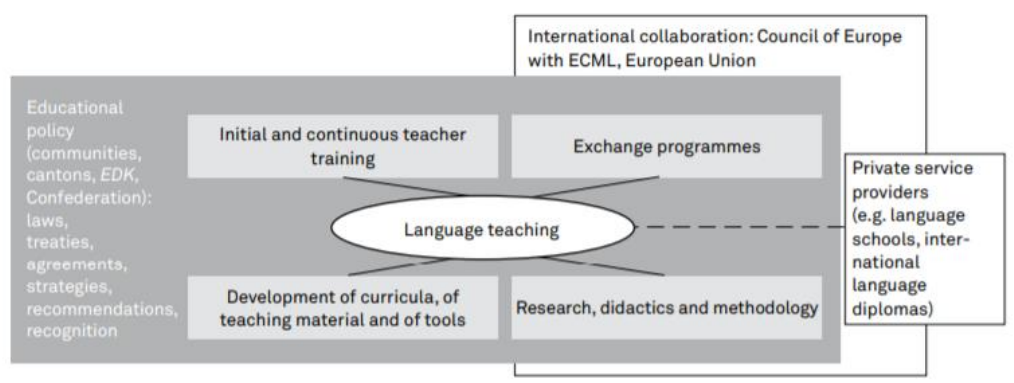

Illustration 1

Language Teaching Policy of Switzerland (Hutterli, 2012)

Other important sources for effective language teaching are the curriculum and materials. Teachers actively participate in curriculum development and material design procedures. The students are also given materials ranging from books to language cards.

Multilingualism is the main focus of language lessons in Switzerland. With the local official language at least two other foreign languages are taught in schools (Wokusch \& Lys, 2007)

Language teaching starts at the pre-school level, that is a case also for the students attending an international school. The main aim of pre-schools is giving students linguistic awareness. Students learn at this stage that there are many languages on earth and some of their classmates speak these languages.

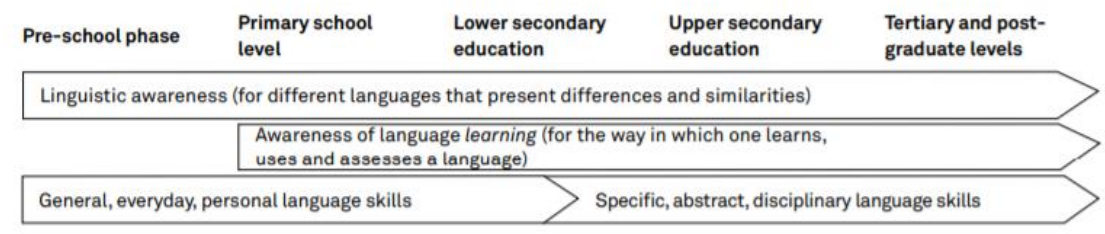

Illustration 2

School learning contexts and their potentials (Hütterli, 2012)

In the primary level, students start to learn languages with their rules. Natural learning environment turns into systematic language teaching. During their compulsory school time students learn the colloquial language, but when they start upper secondary education they start to get specific language teaching.

English knowledge is seen as a key to learn other foreign languages. Studies showed that students with good English has an improved meta-linguistic knowledge and therefore they are better equipped to learn another language (Fulgenzi, 2007)

The general frame of language lessons

As stated before, Switzerland has a unique education system that changes by cantons, But there are also studies to coordinate and standardize these systems. One of them is the HarmoS agreement. The 
exact name of it is "International Agreement on the Harmonisation of Compulsory Schooling". The agreement was signed by German-speaking cantons. The main aims are harmonizing the duration, key objectives, content and transitions in compulsory education in the German part of Switzerland.

The HarmoS Agreement specifies that the teaching of the first foreign language must start no later than the $5^{\text {th }}$ school year and the second foreign language no later than the $7^{\text {th }}$ school year (as per the HarmoS system of counting). One of the foreign languages is to be a second national language and the other English, and optional tuition should be available in a third national language where there is a demand for this. The Agreement leaves it up to the coordinators in the different linguistic regions to specify the order in which the foreign languages should be learned (SKBF, 2014).

The compulsory education is divided into three groups. These are the Pre-school, Primary and Secondary level. The other classification for compulsory education is the circle system. Two years of kindergarten and the first two years of primary school is in the $1^{\text {st }}$ circle. The second circle includes $3^{\text {rd }}$ to $6^{\text {th }}$ classes and the last circle is like upper-secondary level and includes $7^{\text {th }}$ to $9^{\text {th }}$ classes.

The purposes of preschools/kindergartens are different in the three language regions of Switzerland. In the Swiss German part (kindergarten), educators give more importance to socio-pedagogical education, while its function in the French (école enfantine) and Italian speaking (Scuola dell'infanzia) parts of the country is to prepare the children for the primary school (SES, 2015). Generally, classes consist of 30 percent of migrant children, so language teaching is an important part of preschool education.

Table 1

Number of Language Lessons at Primary Level in German-Speaking Cantons (EDK, 2018).

\begin{tabular}{lllllllllllll}
\hline Level & Preschool & \multicolumn{4}{c}{ Primary Level } & \multicolumn{3}{c}{ Secondary Level } \\
\hline Circle & First Circle & \multicolumn{4}{c}{ Second Circle } & \multicolumn{3}{c}{ Third Circle } \\
\hline Class & KG1 KG2 & 1 & 2 & 3 & 4 & 5 & 6 & 7 & 8 & 9 \\
\hline German & & & 6 & 6 & 5 & 5 & 5 & 5 & 5 & 5 & 4 \\
\hline $1^{\text {st }}$ Foreign Language & & & & 3 & 3 & 2 & 2 & 3 & $2-3$ & $2-3$ \\
\hline $2^{\text {nd }}$ Foreign Language & & & & & & $2-3$ & $2-3$ & 3 & 3 & 3 \\
\hline
\end{tabular}

The Swiss school system wants to raise students who are good at their own language and other languages. German is given in all grades and has the biggest part in the weekly schedule. English is given as the first foreign language and taught after third class. One of the country languages is given as second foreign language when students start $5^{\text {th }}$ class. At the end of the $9^{\text {th }}$ class, All students have a really good German knowledge, can speak English fluently and can communicate with a second foreign language.

As stated before, language education is very important in the Swiss education system. At the end of $5^{\text {th }}$ class, students have to be taught at least one foreign language and one of these must be German in Swiss-French cantons and French in Swiss-German cantons. The application of this policy is like that in most Swiss-German cantons this procedure is followed. English is given as the first foreign language at grade 3, French as the second foreign language; in most Swiss-French cantons, German is given as first foreign language at grade 3, and English as the second at grade 5.

Language learning is important for students' future education carrier. Language lessons are one of the criteria for deciding students upper secondary school type. For example in the Swiss-French part of the country, from the $5^{\text {th }}$ year, the pupils' work is noted in the evaluation report, except in German. From the $6^{\text {th }}$ year on, pupils' work is also noted in German.

In $6^{\text {th }}$ grade, a collective evaluation is carried out to locate students into an appropriate lower secondary school. The decision is made with parents, teachers, and student together. The principal 
says the last word after this evaluation. Students are divided into "general section", "modern section" or "section preparing for mature schools". Teaching in the first language of the Canton, Mathematics and two foreign language disciplines are done in the A, B and C levels. The teaching of the other subjects is done in their respective classes (class $\mathrm{g}, \mathrm{m}$ or $\mathrm{p}$ ). Students in gymnasium type schools have to finish sets of tasks (maturitatarbeit) to qualify their education. The gymnasial teaching begins in $11^{\text {th }}$ grade $\left(3^{\text {rd }}\right)$. Depending on the municipality, it takes place in a high school or in a gymnasium. At this decision point, success in language lessons is one of the key factors.

At lower secondary level, students are educated in all subjects or some selected subjects taught in performance groups. There are different forms of organization (for example, separate classes or common classes with level instruction in individual subjects). The aim of this level is to prepare students for vocational or general academic education, which they will meet in the second part of their secondary education. During the first part of secondary level schools emphasize language lessons. Students are to know their local language and also they should have a basic information on one of the national languages of Switzerland. Also, All schools teach at least a foreign language.

Table 2

Zurich Lower Secondary Language Lessons (Zurich Ministry of Education, 2018)

\begin{tabular}{|c|c|c|c|c|c|c|}
\hline & & $1^{\mathrm{st}}$ & $2^{\text {nd }}$ & $3^{\text {rd }}$ Year $(\mathrm{A})$ & $3^{\text {rd }}$ Year $(\mathrm{B})$ & $3^{\text {rd }}$ Year $(C)$ \\
\hline \multirow[t]{7}{*}{ Languages } & German & 5 & 5 & 4 & 4 & 4 \\
\hline & English & 3 & 3 & 2 & & \\
\hline & French & 3 & 3 & 3 & & \\
\hline & & & & 1 to 3 & 1 to 3 & 1 to 3 \\
\hline & Optional English & & & 1 & 3 & 3 \\
\hline & Optional French & & & 1 & 3 & 3 \\
\hline & Optional Italian & & & 3 & 3 & 3 \\
\hline
\end{tabular}

After the compulsory school time, children continue their education at the upper secondary level. Upper secondary schools consist of vocational and academic schools. These schools can be listed under three titles; Gymnasiums, Fach- or Wirschaft middle schools. There are also certificate programs (Berufslehre) and full-time vocational schools. The education time in these schools are 3-4 years and the main aim of this time is to prepare the students to Tertiary Level (Universities, Technical Colleges and other special courses that prepares students to federal vocational exams as well as high technical exams.)

This level is not compulsory but $\% 90$ of the Swiss teenagers took a degree at the upper secondary level and \%20 percent of all the Swiss children attend matura schools (Gymnasiums). The maturity certificates given by these schools are valid for admission to all Swiss universities no matter where they are taken. Among upper secondary students in Switzerland who are beyond the typical age of enrollment (i.e. over 24 years old), $88 \%$ are enrolled in vocational programmes, compared to the OECD and EU22 averages of $71 \%$ and $74 \%$ respectively (OECD, 2017)

Gymnasiums are the top schools in the Swiss education system. The main aim of these schools is to prepare students for the baccalaureate. This education takes four years. The first year is accepted as a transition class and the other three years are can be considered as baccalaureate school. The certificate of baccalaureate gives access to all the universities, polytechnic school, pedagogy universities, and other vocational tertiary level schools. In 2012, $19 \%$ of the 19-year-old Swiss people have baccalaureate certificate taken from a Gymnasium.

Few languages are taught at gymnasiums. In tables 4 and 5 weekly language lesson programmes of Bern Kirchenfeld Gymnasium are given. 
Table 4

Compulsory Language lessons in Kirchenfeld Gymnasium

\begin{tabular}{lccccccccc}
\hline Compulsory Lessons & Class & 1 & & 2 & & 3 & & 4 & \\
\hline & Term & 1 & 2 & 1 & 2 & 1 & 2 & 1 & 2 \\
\hline German & & 4 & 4 & 4 & 4 & 3 & 3 & 4 & 4 \\
\hline French & & 4 & 4 & 3 & 3 & 3 & 3 & 3 & 3 \\
\hline Basic subject English/Latin & 3 & 4 & 4 & 3 & 3 & 3 & 4 & 3 \\
\hline Basic subject Latin & 3 & 4 & 3 & 3 & 3 & 3 & 3 & 3 \\
\hline $\begin{array}{l}\text { Basic subject Latin (without } \\
\text { prior knowledge) }\end{array}$ & 4 & 4 & 4 & 4 & 4 & 4 & & \\
\hline
\end{tabular}

Table 5

Optional Language Lessons in Kirchenfeld Gymnasium.

\begin{tabular}{|c|c|c|c|c|c|c|c|c|c|}
\hline Compulsory Lessons & Class & 1 & & 2 & & 3 & & 4 & \\
\hline & Term & 1 & 2 & 1 & 2 & 1 & 2 & 1 & 2 \\
\hline $\begin{array}{l}\text { English (with previous knowledge } \\
\text { In 7., 8. Classes) }\end{array}$ & & 4 & 4 & 4 & 4 & 3 & 3 & 4 & 4 \\
\hline Italian (with previous knowledge in 8 . Class) & & 4 & 4 & 3 & 3 & 3 & 3 & 3 & 3 \\
\hline Latein (with previous knowledge in 8 . Class) & & 3 & 4 & 4 & 3 & 3 & 3 & 4 & 3 \\
\hline Intensive Italian & & 3 & 4 & 3 & 3 & 3 & 3 & 3 & 3 \\
\hline Latin & & 4 & 4 & 4 & 4 & 4 & 4 & & \\
\hline Russian & & & 3 & 3 & 3 & 3 & 3 & 3 & \\
\hline Italian & & & & 2 & 2 & 2 & 2 & & \\
\hline Spanish & & & & 2 & 2 & 2 & 2 & & \\
\hline $\begin{array}{l}\text { DALF (Diplôme Approfondi de Langue } \\
\text { Française) }\end{array}$ & & & & & & 1 & 1 & & \\
\hline CPE (Certificate of Proficiency in English) & & & & & & & 1 & 1 & \\
\hline CAE (Certificate of Advanced English) & & & & & & & & 1 & \\
\hline
\end{tabular}

\section{Language Teaching Strategies}

Because of Switzerland's unique conditions. Language learning is no longer considered as the separate acquisition of several languages but as the development of an integrated plurilingual and intercultural competence. It is an overarching competence that students acquire in the general context of the school, reinforced by being spread among several subjects and teachers. To do this, firstly, the objectives that are set for each of the languages must be harmonized in order to establish cross-language learning synergies. In addition, more attention must be given to the language aspects of non-language subjects, by harmonizing their objectives with those of the language of schooling for instance (Hutterli, 2012). This integrated language teaching method is based on psycholinguistic approach (Wokusch \& Lys, 2007).

All language learning should be accompanied by cultural learning and is most effective when implicit learning and explicit learning complement each other. To trigger implicit learning processes in the most natural way possible it is important to emphasize content. Multilingually oriented language teaching methodology, therefore stresses the development of language in relation to culture on the one hand, and language in relation to content on the other (Hütterli, 2012). The main characteristics of this methodology are given in Table 6 below: 
Table 6

Multilingually oriented language teaching methodology / integrated language teaching methodology: objectives and example. (Hütterli, S. (2012). Coordination of Language Teaching in Switzerland. EDK: Bern)

\begin{tabular}{|c|c|c|}
\hline $\begin{array}{l}\text { Objective, } \\
\text { characteristic }\end{array}$ & Methodology & Examples \\
\hline \multirow[t]{2}{*}{$\begin{array}{l}\text { Integrated } \\
\text { language } \\
\text { promotion }\end{array}$} & $\begin{array}{l}\text { Work with a cross-curricular and } \\
\text { possibly comparative approach among } \\
\text { languages in text genres and language tasks }\end{array}$ & $\begin{array}{l}\text { summaries, accounts, } \\
\text { arguments }\end{array}$ \\
\hline & Carry out cognitive linguistic tasks & $\begin{array}{l}\text { selecting and organizing information, taking } \\
\text { notes, constructing an argument }\end{array}$ \\
\hline \multirow[t]{3}{*}{$\begin{array}{l}\text { Language } \\
\text { education }\end{array}$} & $\begin{array}{l}\text { Address various language functions and practice } \\
\text { them }\end{array}$ & $\begin{array}{l}\text { language as the medium of thinking, expressing } \\
\text { oneself and communicating }\end{array}$ \\
\hline & $\begin{array}{l}\text { Define and understand linguistic norms by } \\
\text { using examples taken from different languages }\end{array}$ & the use of the passive in various languages \\
\hline & $\begin{array}{l}\text { Understand the relation between } \\
\text { communication situations and linguistic } \\
\text { resources; also in comparison with different } \\
\text { cultures }\end{array}$ & $\begin{array}{l}\text { forms of greeting and leave-taking; composing } \\
\text { an e-mail message }\end{array}$ \\
\hline \multirow{3}{*}{$\begin{array}{l}\text { Openness to } \\
\text { other } \\
\text { languages and } \\
\text { cultures }\end{array}$} & $\begin{array}{l}\text { Integrate ELBE (language awareness) or EOLE } \\
\text { (language education and awareness in school) } \\
\text { processes and approaches to teaching }\end{array}$ & $\begin{array}{l}\text { the rules applied in the schools of different } \\
\text { countries }\end{array}$ \\
\hline & $\begin{array}{l}\text { Proceed through observation and comparison } \\
\text { with respect to social and cultural issues }\end{array}$ & $\begin{array}{l}\text { through the exchange of e-mails with a partner } \\
\text { class in a region where a different language is } \\
\text { spoken }\end{array}$ \\
\hline & $\begin{array}{l}\text { Integrate education through contact into } \\
\text { teaching and encourage the development of } \\
\text { intercultural competence }\end{array}$ & \\
\hline \multirow{5}{*}{$\begin{array}{l}\text { Development } \\
\text { of } \\
\text { methodologica } \\
1 \text { and strategic } \\
\text { competence }\end{array}$} & $\begin{array}{l}\text { Develop and practise reading, comprehension, } \\
\text { and strategies in a coordinated manner; } \\
\text { similarly for auditory and visual comprehension } \\
\text { processes }\end{array}$ & $\begin{array}{l}\text { by introducing reading strategies and their use } \\
\text { in different languages }\end{array}$ \\
\hline & $\begin{array}{l}\text { Develop writing processes, create and practise } \\
\text { writing and revision strategies in a coordinated } \\
\text { manner }\end{array}$ & $\begin{array}{l}\text { by introducing brainstorming techniques for a } \\
\text { language and additional practice for other } \\
\text { subjects }\end{array}$ \\
\hline & $\begin{array}{l}\text { Develop and practise communication strategies } \\
\text { in a coordinated manner (use of language } \\
\text { strategies), for oral use and particularly for } \\
\text { interaction }\end{array}$ & facial expressions and gestures \\
\hline & $\begin{array}{l}\text { Develop and practise learning strategies in a } \\
\text { coordinated manner }\end{array}$ & by using a vocabulary list \\
\hline & Manage auxiliary resources and means & by using dictionaries and reference works \\
\hline \multirow{4}{*}{$\begin{array}{l}\text { Promotion of } \\
\text { individual } \\
\text { plulingualism }\end{array}$} & $\begin{array}{l}\text { Integrate language and culture of origin } \\
\text { teaching }\end{array}$ & using the European Language Portfolios [ELP] \\
\hline & $\begin{array}{l}\text { Show the connections that exist between } \\
\text { languages }\end{array}$ & $\begin{array}{l}\text { English technological and sports terms in other } \\
\text { languages, French expressions in English, such } \\
\text { as «a feeling of déjà vu» }\end{array}$ \\
\hline & $\begin{array}{l}\text { Coordinate work with the European Language } \\
\text { Portfolios (ELP) (for example, }\end{array}$ & $\begin{array}{l}\text { by introducing and practising strategies across } \\
\text { different language subjects; specific reflection } \\
\text { on language with the help of the ELP }\end{array}$ \\
\hline & $\begin{array}{l}\text { Take into account the inter-comprehension } \\
\text { approach in teaching }\end{array}$ & $\begin{array}{l}\text { by decoding a text with the help of similar } \\
\text { words in other languages }\end{array}$ \\
\hline
\end{tabular}




\begin{tabular}{|c|c|c|}
\hline & Introduce students to mediation and practise it & $\begin{array}{l}\text { by summarising the essence of a foreign } \\
\text { language text in the language of schooling }\end{array}$ \\
\hline \multirow{5}{*}{$\begin{array}{l}\text { Development } \\
\text { of functional } \\
\text { language skills }\end{array}$} & $\begin{array}{l}\text { Work on the different areas of language } \\
\text { competences }\end{array}$ & $\begin{array}{l}\text { by learning the vocabulary specific to a given } \\
\text { situation }\end{array}$ \\
\hline & $\begin{array}{l}\text { Practise language skills in a specific and } \\
\text { targeted manner }\end{array}$ & productive and receptive skills; interaction \\
\hline & Analyze needs and act according to the situation & $\begin{array}{l}\text { by having students, choose texts and carry out } \\
\text { tasks }\end{array}$ \\
\hline & Integrate task-based teaching processes & task-based language learning \\
\hline & $\begin{array}{l}\text { Take into account content-based teaching } \\
\text { processes }\end{array}$ & CLIL, content and language integrated learning \\
\hline \multirow{4}{*}{$\begin{array}{l}\text { Use-oriented } \\
\text { language } \\
\text { learning }\end{array}$} & Define tasks & $\begin{array}{l}\text { by creating communication situations that are as } \\
\text { real as possible }\end{array}$ \\
\hline & Work with realistic models & $\begin{array}{l}\text { by creating dialogue models based on real } \\
\text { situations }\end{array}$ \\
\hline & Integrate socio-cultural aspects & $\begin{array}{l}\text { by comparing typical conversations or manners } \\
\text { in different cultures }\end{array}$ \\
\hline & $\begin{array}{l}\text { Work preferably with lexicalized grammar and } \\
\text { extended lexical units }\end{array}$ & $\begin{array}{l}\text { by thematically presenting and learning models } \\
\text { of sentence construction and collocations }\end{array}$ \\
\hline \multirow{2}{*}{$\begin{array}{l}\text { Availability of } \\
\text { adequate } \\
\text { implicit } \\
\text { learning } \\
\text { opportunities }\end{array}$} & Integrate content-based teaching processes & CLIL \\
\hline & Promote education through contact & through student exchanges \\
\hline \multirow{3}{*}{$\begin{array}{l}\text { Development } \\
\text { of intercultural } \\
\text { competence }\end{array}$} & Address cultural differences and similarities & $\begin{array}{l}\text { by comparing nursery rhymes or jokes in } \\
\text { different languages }\end{array}$ \\
\hline & $\begin{array}{l}\text { Address socio-cultural issues through } \\
\text { observation and comparison }\end{array}$ & $\begin{array}{l}\text { by comparing recommendations regarding } \\
\text { eating habits in different countries, with } \\
\text { different languages }\end{array}$ \\
\hline & Promote education through contact & $\begin{array}{l}\text { through the exchange of video messages with } \\
\text { another class, in another language }\end{array}$ \\
\hline \multirow{4}{*}{$\begin{array}{l}\text { Development } \\
\text { of lexical and } \\
\text { formal } \\
\text { competence }\end{array}$} & $\begin{array}{l}\text { Take a lexical approach to grammar, through } \\
\text { mainly idiomatic, lexicalized structures }\end{array}$ & $\begin{array}{l}\text { recognize and practise typical pivotal words, } \\
\text { learn verbs and complements together }\end{array}$ \\
\hline & $\begin{array}{l}\text { Take into account, for the formal aspects, } \\
\text { consciousness-raising teaching processes }\end{array}$ & $\begin{array}{l}\text { by deducing a grammatical rule based on } \\
\text { examples }\end{array}$ \\
\hline & $\begin{array}{l}\text { Work with BICS using situations, with the help } \\
\text { of expressions and formulaic language }\end{array}$ & everyday conversations \\
\hline & $\begin{array}{l}\text { Work with CALP to differentiate between } \\
\text { meanings of vocabulary, compare syntactic } \\
\text { models or typical expressions according to } \\
\text { functional criteria }\end{array}$ & $\begin{array}{l}\text { by working on the contrast between the passive } \\
\text { in German and the use of «on» in French in the } \\
\text { impersonal formulation }\end{array}$ \\
\hline \multirow{2}{*}{$\begin{array}{l}\text { Taking into } \\
\text { account the } \\
\text { age and } \\
\text { cognitive style } \\
\text { of the learner }\end{array}$} & $\begin{array}{l}\text { Foster the development of BICS among younger } \\
\text { learners and familiarise them with CALP }\end{array}$ & through CLIL \\
\hline & $\begin{array}{l}\text { Make better use of and develop CALP among } \\
\text { older learners }\end{array}$ & $\begin{array}{l}\text { by means of the bilingual teaching of non- } \\
\text { language subjects }\end{array}$ \\
\hline
\end{tabular}

\section{CONCLUSION, DISCUSSION AND SUGGESTIONS}

The main aim of education is to raise children who have the needed qualifications of the society (White, 2006). A Swiss person needs more than a language to get a good life in the country's compelling work life so language education in Switzerland was designed to meet this need. Because of the countries multilingual and multicultural identity, many bridges have been built between the 
different languages - the languages of schooling, foreign languages and languages of origin / of migration, national languages and English (Hutterli, 2012).

According to Wokusch (2008) states that multilingual individuals are desired in the European world and having a multilingual competence is a key factor in school success. Likewise, the Swiss school system uses an integrated teaching method that will promote students' polylingualism.

Integrated language learning is more suitable to human nature as learning must be integrated into a pre-existing set (Brohy, 2008). In accordance with this idea, language lessons are connected with other language and culture lessons. Language curriculums are focused on common points of language forms, vocabularies, etc.

In language lessons, recent approaches like Task-Based Language Teaching and Content and Language Integrated Learning are widely accepted. These approaches have been proven to be effective in various studies (Demir, 2008; Soyaslan, 2008; Demir, 2009; Cebeci, 2016; Rahman, 2016; Alkan 2017).

To sum up, Switzerland has adopted a language teaching model which is perfect for its unique status. Teaching a language is not seen as an isolated process, instead, it takes one's nearly all education life starting in preschool. Also, teaching language and culture awareness is vital for Switzerland's future as the country consists of many languages and cultures.

People learn languages best when they need them. Education system makes students learn languages to communicate, to learn other subjects and to be successful in their future life.

Although language teaching considered as a universal subject, It is concluded from Switzerland case that countries should adopt the approaches and methods for their unique condition and to develop integrated language curriculums.

\section{REFERENCES}

Alkan, E. (2017). Perceptions of EFL learners towards task-based CUE lessons (MA Thesis). Akdeniz University, Antalya.

Bowen, Glenn A., 2009, 'Document Analysis as a Qualitative Research Method', Qualitative Research Journal 9 (2), 27-40. DOI 10.3316/QRJ0902027.

Brohy, C. (2008). Didactique intégrée des langues: évolution et définitions. In. Brohy, C. \& Rezgui, S., La didactique intégrée des langues: expériences et applications, Comano, 9-11.

Cebeci, N. (2006). The effectivity of task-based activities on vocabulary competence design in accordance with the common European framework (MA Thesis). Trakya University, Edirne.

Demir, A. (2008). The Influence of Task-Based Reading Activities on EFL Learners' Attitude and Learning Outcomes From the Students' Perspective (MA Thesis). Çukurova University, Adana.

Demir, M. (2009). Imamhatip liselerinde Arapça konuşma öğretimine etkinlik temelli bir yaklaşım (MA Thesis). Gazi University, Ankara.

Denzler- Schircks, S., (2014). Educational Research and Development in Switzerland: Country Background Report. Aarau: Swiss Coordination Centre for Research in Education.

Engler, B. (2008). English Studies in Switzerland. European English Studies: Contributions towards the History of a Discipline II, ed. by Renare Haas and Balz Engler. The English Association for ESSE: Leicester. 
Flyvbjerg, B. (2011). Case study. In Norman, K, Denzin and Yvonna, S. Lincoln, eds., The Sage Handbook of Qualitative Research, $4^{\text {th }}$ Edition (Thousand Oaks, CA)

Fredriksson, U., Holzer, T., McCluskey-Cavin, H. \& Taube, K. (2009). Strengths and weaknesses in the Swedish and Swiss Educations systems: A comparative analysis based on PISA data. European Education Research Journal, 8(1). 54-68.

Frei, R. (2011). Complex systems approach to education in Switzerland. In T. Lenaerts, M. Giacobini, H. Bersini, P. Bourgine, M. Dorigo, \& R. Doursat (Eds.), Advances in artificial life, ECAL 2011: proceedings of the eleventh European conference on synthesis and simulation of living systems (pp. 242-249). MIT.

Fries, A. \& Edelmann, D., (2002). Allocation of Instruction Periods and Teaching Subjects in Switzerland Curriculum Change in the Canton of Zurich between 1991-2002, Zurich University of Applied Sciences School of Education Department of Research and Development.

Fulgenzi, E. 2007. Switzerland and the Federal Law on National Languages and Comprehension between Linguistic. Retrieved September 9, 2015, from https:// vernaculum.files.wordpress.com/2011/10/elisa-6.pdf.

Huppka, S., Sachi, S. \& Stalder, B. (2006). Does the Swiss VET System encourage inequity? Paper presented at European Research Network on Transitions in Youth TIY Workshop " Vocationalisation of Education: how, where, when, why and in what sense does it matter?". Marseilles. Retrieved from http://www.tree.unibe.ch/e206328/e305140/e305154/files307489/Hupka_Sacchi_Stalder_2006_VET_ en_ger.pdf.

Hütterli, S. (2012). Coordination of Language Teaching in Switzerland. EDK: Bern

Liensen, C. (2011). Making Schools Responsible for Students with Special Needs: Swiss Country Report. Retrieved from https://www.hfh.ch/fileadmin/files/documents/Dokumente_FE/D.20_CountryReport---Switzerland-by-C-Liesen.pdf on 12.03.2018.

Meyer, T. \& Bertschy, K. (2011). The long and winding road from education to labor market: The TREE cohort six years after leaving compulsory school. In. Bergman, M., Hupka-Brunner, S., Keller, A., Meyer, T. \& Stalder, B. E., Youth Transitions in Switzerland: Results from the TREE Panel Study, Zurich, 92-119.

OECD. (2003). Tertiary Education in Switzerland. Paris: OECD.

OECD. (2012). Post-secondary attendance of immigrants in Switzerland and Canada. OECD (Ed.) In Untapped Skills: Realising the Potential of Immigrant Students. Paris: OECD.

OECD. (2017). Education at a Glance 2017: Switzerland Country Note. Retrieved from http://www.oecd-ilibrary.org/education/education-at-a-glance-2017/switzerland_eag-2017-69-en on 12.03.2018

Oelkers, J. (2002). System research, Piaget and the development of the Swiss curriculum. Retrieved from https://www.ife.uzh.ch/dam/jcr:fffffff-bb47-55f9-ffff-ffffbc739485/Hottingendef.pdf on 11.03.2018.

Oelkers, J. (2014). German "Bildung" and the Education of Teachers. Retrieved from https://www.ife.uzh.ch/dam/jcr:ffffffff-bb47-55f9-00000000745cd0f4/Leipzig_German _Bildung_engl.pdf on 11.03.2018.

Rahman, S. H. (2016). A task-based approach to teaching English vocabulary skill to iraqian EFL learners (MA thesis). İstanbul Aydın University, İstanbul. 
Ronan, P. (2016). Perspectıves on English in Switzerland. Cahiers de 1'ILSL 48, 9-26.

SKBF, (2014). Bildungsbericht Schweiz 2014, Aarau: Schweizerische Koordinationsstelle für Bildungsforchnung.

Soyaslan, F. N. (2008). The effects of task-based teaching on foreign language achievement of $6^{\text {th }}$ grade students in Manisa Yavuz Selim Primary Education School (MA Thesis). Dokuz Eylül University, İzmir.

Stake, R. E. (1995). The Art of Case Study Research. Thousand Oaks: Sage.

The languages of Switzerland. (n.d.) In Wikipedia, Retrieved 11.03.2018, from https://en.wikipedia.org/wiki/Languages_of_Switzerland.

White J (2006). Intelligence, Destiny and Education: the ideological origins of intelligence testing, London: Routledge

White, M. D. \& Marsh, E. (2006). Content analysis: A flexible methodology. Library Trends, 55(1). $22-45$.

Wokusch, S. (2008). Didactique intégrée des langues: la contribution de l'école au plurilinguisme des élèves. In. Brohy, C. \& Rezgui, S., La didactique intégrée des langues: expériences et applications, Comano, 12-14. 